\title{
黒鉛でカプセル化した鉄粒子の調製と構造
}

\author{
今村 健*, 西久保桂子*, 山田泰弘*, 高島正樹**, 奥山公平**
}

(平成7 年 12 月 18 日受理)

\section{Preparation and Microstructure of Graphite-encapsulated Iron Sphere}

Takeshi Imamura, Keiko Nishikubo, Yasuhiro Yamada, Masaki Takashima* and Kouhei Okuyama*

Kyushu National Industrial Research Institute, Shuku-machi, Tosu, Saga 841, Japan

* Yokohama Research Center, Mitubishi Chemical Co., 1000, Kamoshida, Aoba-ku, Yokohama 227,. Japan

It is known that dissolved carbon in the molten Iron $(\mathrm{Fe})$ crystalizes out as graphite on cooling. Graphite-encapusulated $\mathrm{Fe}$ sphere was prepared by using this process.Mixture of carbon black and 45 atm $\% \mathrm{Fe}$ powder was heat-treated at $2500{ }^{\circ} \mathrm{C}$ and then the magnetic product was separated from the residure. The product was $\alpha$-Fe sphere wrapped in graphite. The sphere was $0.25-100 \mu \mathrm{m}$ in diameter and contained $92 \mathrm{wt} \%$ of $\mathrm{Fe}$. The thermogravimetric analysis of the sphere in oxidative atmosphere showed thata weight loss sets in at $730^{\circ} \mathrm{C}$, as well as a natural graphite. Magnetization curve did not exhibit the hysteresis loop and saturation magnetization was $189 \mathrm{emu} / \mathrm{g}$ corresponding to Fe content. From those results, it was concluded that the graphite-encapsulated $\mathrm{Fe}$ sphere is ferromagnetic and stable in oxidative atmosphere.

KEYWORDS : Iron particle, Graphite-encapsulation, Microstructure, Magnetic property

\section{1. はじめに}

鉄等の遷移金属を含む黒鉛を陽極としたアーク放電によ り，陰極側のスス中に黒鉛でカプセル化した金属粒子が生 成することが報告されている1)-3)。その大きさは院極電極 に黒鉛を用いた場合は約 $40 \mathrm{~nm}^{1)}$, タングステンの場合で7 〜 $14 \mathrm{~nm}^{2)}$ であり, いずれもナノ結晶金属の球形粒子の表 面に添って炭素層面が配列した構造である。黒鉛でカプセ ル化することは大気中で不安定な金属を保護し，しかも， その大きさから磁気的性質等に特異的な物性を発現する新 しい材料であると考えられる。

一方, 鉄は溶融状態で炭素を溶解し, 冷却過程で黒鉛が 析出することはよく知られている4)。炭素が溶解した溶融 鉄を表面張力で球形化し，この形状を保持したまま冷却す ることができれば，冷却時に球状の鉄表面に黒鉛が析出し，

工業技術院九州工業技術研究所： 7841 鳥栖市宿町

*三菱化学侏横浜総合研究所： 7227 横浜市青葉区鴨志 田町 1000
カプセル化が可能となる。この考えに基づいて，粉末の炭 素と鉄の混合物を $1200^{\circ} \mathrm{C}$ 以上の温度で熱処理したところ, 黒鉛でカプセル化した鉄粒子の調製が可能であった。

ここでは, 主として黒鉛でカプセル化した鉄粒子の構造 を調べた結果について報告する。

\section{2. 実験方法}

\section{1 試料}

炭素として平均粒子径 $15 \mathrm{~nm}$ のカーボンブラック ( $\mathrm{CB}$, 三菱化学\#2300), 鉄 $(\mathrm{Fe})$ として平均粒子径 $10.9 \mu \mathrm{m}$ の $\alpha-\mathrm{Fe}$ (片山化学試薬) を用いた。

\section{2 熱処理と分離}

$\mathrm{CB}$ と $45 \mathrm{~atm} \% \mathrm{Fe}$ (配合量 $20 ： 80 \mathrm{wt} \%$ ) を混合し,こ れを黒鉛製ルッボに入れ，アルゴン気流中， $2500{ }^{\circ} \mathrm{C} て ゙ 60$ $\min$ 保持して熱処理した。この熱処理物をエタノール中に 入れ, 超音波分散し, 約 $1 \mathrm{~min}$ 静置した後, 容器底の外部 に磁石を置き上澄みを除いた。残渣に新たなエタノールを 加え，上澄み液が透明になるまで上記と同様の操作を $5 \sim 6$ 回繰り返した後, 残渣を乾燥した。 


\section{3 形態と構造}

沈降物の形態を走査型電子顕微鏡（SEM，トプコン社製 SIGMA1）で，元素組成とその分布状態をSEM付属の工ネ ルギー分散型X 線分析装置 (EDX, Philips 社製 EDAX PV9900）で調べた。また，Fe 含有量は硫酸，硝酸および 過塩素酸の混酸中で加熱分解した後, ICP 発光分光分析法 で定量した。構造として粉末X線回折法で結晶相を，透過 型電子顕微鏡 (TEM) で微構造を調べた。X線回折はりガク 製RU-200B を用い, TEM は日本電子製2000FXを用いた。

\section{4 酸化挙動と磁気的性質}

酸化挙動は熱天秤（TG，真空理工製 TG7000）により, 酸素33vol \%を含む窒素ガス流通下， $1500{ }^{\circ} \mathrm{C}$ (昇温速度 $5{ }^{\circ} \mathrm{C} / \mathrm{min}$ ）まで加熱したときの重量変化から調べた。磁気 的性質は振動試料型磁気測定装置（東英工業製VSM-3S） を用い, 空気中, 約 $25^{\circ} \mathrm{C}$ 室温で磁化曲線を測定した。

\section{3. 結果と考察}

\section{1 沈降物の形態と元素組成}

$\mathrm{CB}$ と $\mathrm{Fe}$ の混合物を $25000^{\circ} \mathrm{Cで}$ 熱処理して得られた沈降物 の形態をSEMで観察し, Fig.1に示す。沈降物はすべて球 状であり，その粒子径は約 $0.2 \sim 100 \mu \mathrm{m}$ であった。球状体 の表面は多角形の平板であり（同図 (B)), SEM付属の
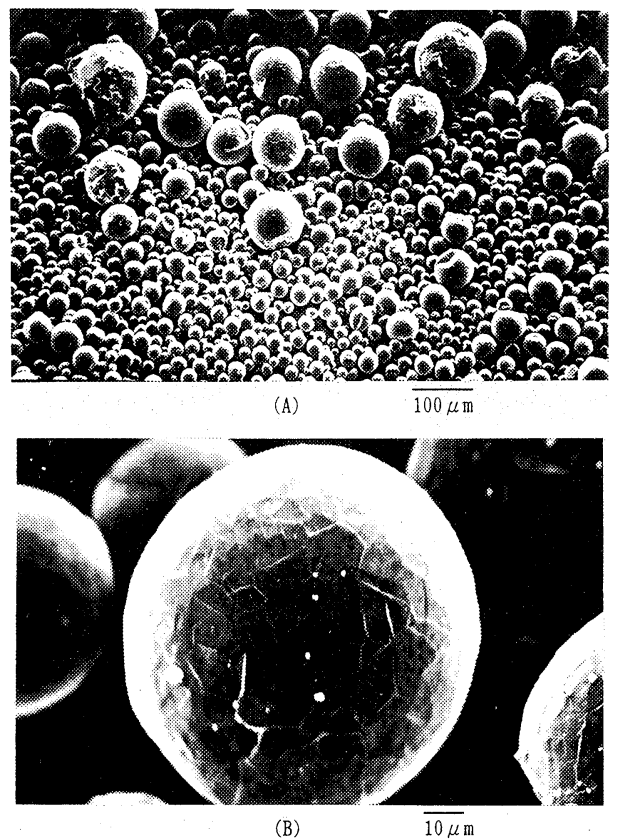

Fig.1 Morphology of the sphere.
(A) sediment (b) surface

EDX で元素組成を調べたところ，炭素（C）と Feが検出さ れた。Cは球全体に分布していたが，FeはX線強度が非常 に弱いため分布を知ることはできなかった。これから, 球 状体表面の多角形平板はCであり，キッシュ黒鉛5) と同じ 形態であることから， $\mathrm{Fe}$ 中から析出したものと考えられる。 球状体の $\mathrm{Fe}$ 含有量は92 wt \%であり，したがって，C量は $8 \mathrm{wt} \%$ となり, 密度 $\left(2.26 \mathrm{~g} / \mathrm{cm}^{3}\right)$ から求めたCの体積は 23 vol \%であった。このC量はFe-C 状態図から, 気相が存 在し得る $2380{ }^{\circ} \mathrm{C}$ での液相線のCの組成（8.4 wt \%) に相当 するので,この組成を維持したまま冷却，析出したものと考え られる。

\section{2 球状体の構造}

球状体の結晶相を粉末 $\mathrm{X}$ 線回折法により調べた。検出さ れた回折線はCと $\alpha-\mathrm{Fe}$ であり，鉄炭化物は検出されなかった。 Cの002 回折線から求めた $\mathrm{d}_{(002)}$ 值は0.3357 nm, Lc (002) は $100 \mathrm{~nm}$ 以上であり, 黒鉛結晶が発達したものであるといえ る。

粒子径の大きい球状体を破壊し，その断面をSEM で観察 し, Fig.2に示す。球状体は二重構造であり，EDXによる

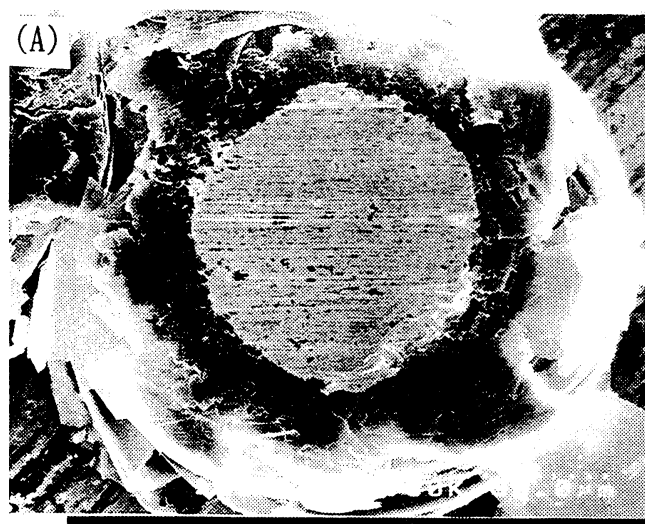

(B)

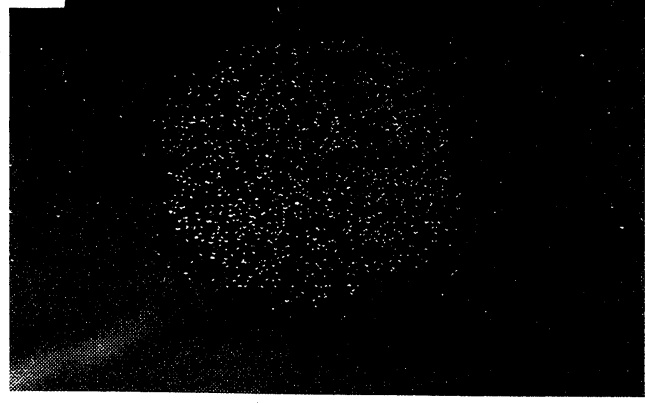

$30 \mu \mathrm{m}$

Fig.2 Cross section of the sphere.

(A) SEM image (B) Fe distribution 


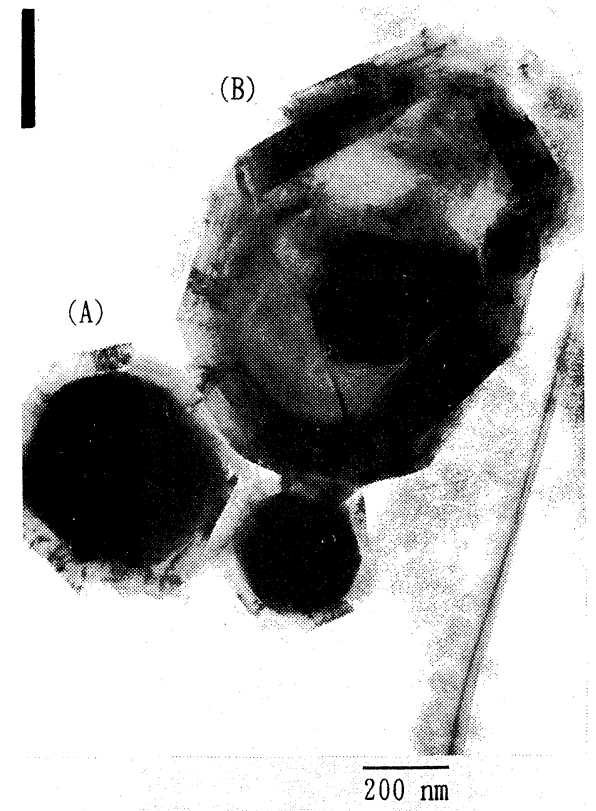

Fig.3 TEM image of the sphere.

(A) sphere filled with $\mathrm{Fe}$, (B) hollow sphere

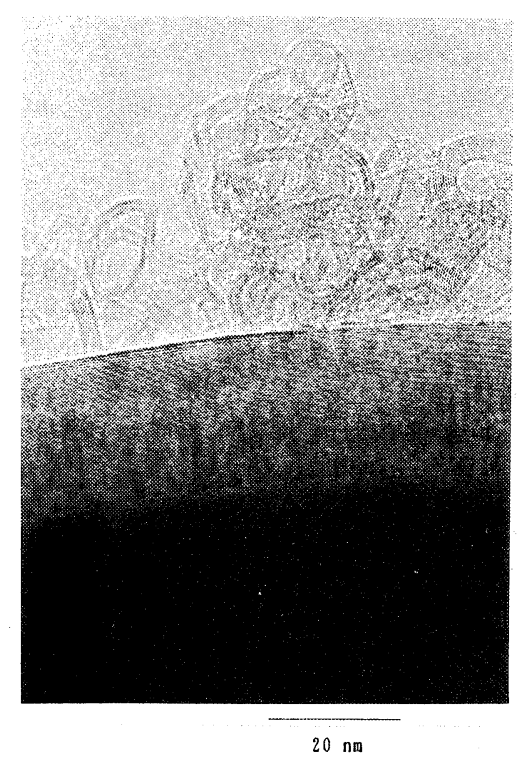

Fig.4 TEM image of the vicinity of the sphere surface.

元素分析から外側はCであり, 内側は同図（B）に示したよ うに, Feであった。これから, 球状体は球形の Fe 粒子が黒 鉛でカプセル化した構造であるといえる。

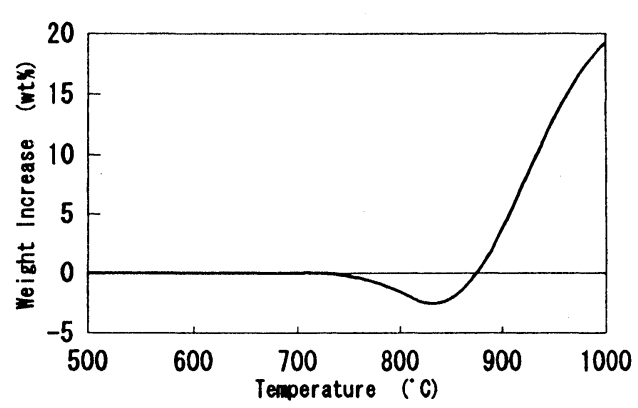

Fig.5 TG curve of the sphere in oxidative atmosphere.

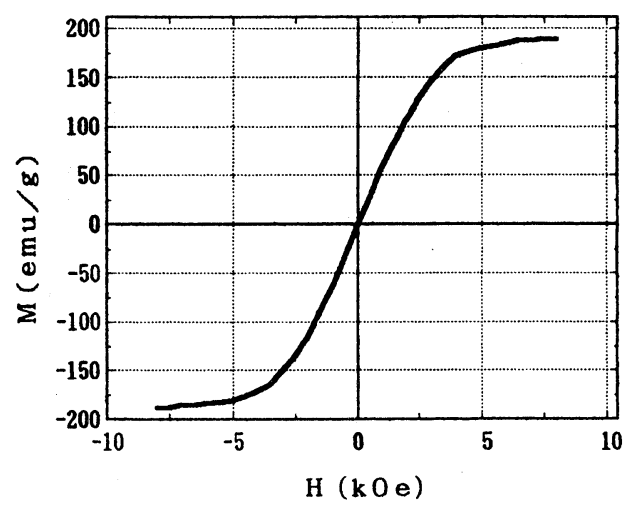

Fig.6 Magnetization curve of the sphere.

粒子径の小さい球状体をTEMで観察し，Fig.3に示す。 Fig.2 と同様な二重構造の微細な球状体（図中A）および中 空と思われる球状体（同B）が認められた。その大きさは 最も小さいもので直径約 $0.25 \mu \mathrm{m}$ であった。TEM付属の EDXによって元素分析を行うと, 球状体 (A) の外側はC のみが, 内部から Feが検出された。中空と思われる球状体 (B) からは外側のC と内部の部分的に Feが検出されたが, 大部分は空陌であった。これらの球状体の外側附近をさら に詳細に観察すると, Fig.4に示したように, いずれも層構 造であり，炭素層面がなめらかに湾曲して球状 $\mathrm{Fe}$ の表面を 被覆している状態であった。炭素層面の状態は球状体 (B) でも同様であったことから, 空隙はFeが蒸発によって除去 された部分であると考えられる。これから, 球の大小にか かわらず，空隙が生成する前の構造に同じであるといえる。 また, 球状体 (A) の電子回折から $\mathrm{Fe}_{3} \mathrm{C}$ に相当する回折線 が検出された。球状体の粉末 $\mathrm{X}$ 線回折では鉄炭化物の回折 線は認められなかったが, 微量の鉄炭化物が存在すること も明らかになった。 
Table 1 Saturation Magnetization of the graphite-encapusulated Fe sphere.

\begin{tabular}{|c|c|c|c|}
\hline & $\begin{array}{l}\text { Saturation Mag. (emu/g) } \\
\text { Experimental Culculated }\end{array}$ & $\begin{array}{l}\text { Density } \\
\left(\mathrm{g} / \mathrm{cm}^{3}\right)\end{array}$ & $\begin{array}{l}\text { Saturation Mag. } \\
\quad(\mathrm{emu} / \mathrm{cc})\end{array}$ \\
\hline Sphere & $189 \quad 201$ & $7.43^{*}$ & 25.5 \\
\hline$\alpha-\mathrm{Fe}$ & 218 & 7.88 & 27.7 \\
\hline$\gamma-\mathrm{Fe}_{2} \mathrm{O}_{3}$ & 74 & 5.24 & 14.1 \\
\hline
\end{tabular}

\section{3 酸化挙動}

上述のように, 球状体は結晶の発達した黒鉛でカプセル 化されていることから，TGによって重量変化を調べた。

TG 曲線をFig.5に示す。 $730^{\circ} \mathrm{C}$ から減量が始まり, 約 $830^{\circ} \mathrm{C}$ から増量が始まった。リン片状天然黒鉛を同じ条件 で重量変化を求めた場合, $730{ }^{\circ} \mathrm{C}$ から減量が始まった。こ の球状体の減量は表面の黒鉛の酸化消耗，増量は $\mathrm{Fe}$ の酸化 によると考えられる。表面の黒鉛か酸化消耗しないあいだ はこの球状体中の Fe が安定に存在することを示している。 $\mathrm{TG}$ 減量から黒鉛の量を求めると約 $2.8 \mathrm{wt} \%$ あ゙あり, Fe含 有量から求めたC 含有量 (8 wt \%) より大幅に少ないが, これはFeの酸化による増量が重なったためと考えられる。

\section{4 磁気的性質}

$\mathrm{Fe}$ は強磁性体であることから球状体の磁化曲線を測定し た。その結果, Fig.6に示したように, ヒステリシスループを 示さず, そのため保磁力は検出されなかった。この磁化曲線 は強磁性微粒子の集合体や合金で認められている超常磁性6) のそれと同様であるが，今後，詳細に検討する予定である。 Table 1 に磁化曲線から求めた飽和磁化の值および $\alpha-F e の$ 飽和磁化とその含有量から求めた飽和磁化の值を計算值と して示す。球状体の值は $189 \mathrm{emu} / \mathrm{g}$ と高く, 計算值は $\alpha-\mathrm{Fe}$ に近い値であった。さらに，単位体積当たりの飽和磁化の

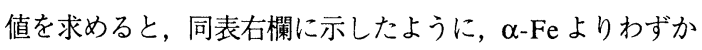
に低いが， $\gamma-\mathrm{Fe}_{2} \mathrm{O}_{3}$ よりも高い值であった。これらのことか ら, 球状体の飽和磁化の值は $\alpha-\mathrm{Fe}$ の含有量に相当し, 安定 な磁気記録用磁性体である $\gamma-\mathrm{Fe}_{2} \mathrm{O}_{3}$ より高いことが分った。 以上のことから, $\alpha-\mathrm{Fe}$ を黒鉛でカプセル化することにより, 大 気中安定で, 高い飽和磁化を示す磁性体になると考えられる。

\section{4. まとめ}

以上の結果をまとめると次のようであった。

(1) $\mathrm{CB}$ と $\mathrm{Fe}$ の混合物を $2500{ }^{\circ} \mathrm{C} て ゙$ 熱処理することにより球 状体が生成した。この球状体は $\alpha-\mathrm{Fe}$ を黒鉛でカプセル 化した構造であり, 大きさは約 $0.25 \sim 100 \mu \mathrm{m}$ であった。

（2）酸素雲囲気下でのTG 曲線によると, 表面の黒鉛か酸化 消耗されない間はFeが安定に存在すると考えられた。

（3）球状体の磁化曲線はヒステリシスループを示さず, 保 磁力は検出されなかった。また, 飽和磁化の值は 189 $\mathrm{emu} / \mathrm{g}$ であり, $\mathrm{Fe}$ 含有量に相当した。

(4)これらの結果から, 黒鉛でカプセル化した Fe 粒子は大 気中安定な強磁性体であることが知られた。

\section{文献}

1) T. Hihara, H. Onodera, K. Sumiyama, K. Suzuki, A. Kasuya, Y. Nishina, Y. Saito, T. Yoshikawa and M. Okuda, Jpn. J. Appl. Phys. 3 (1993) L24-L25.

2) Vinayak P. Dravid, Jonathon J. Host, M. H. Teng, Brian Elliot Jinha Hwang, D. Lynn Johnson, Thomas O. Mason and Julia R. Weertman, Nature $\mathbf{3 7 4}$ (1995) 602.

3) Y. Saito, Carbon 33 (1995) 979-988.

4）たとえば, 石川敏功, 長沖通, 新・炭素工業 (1970) p.161, 近代編集社.

5）萩原茂示, 鋳鉄研究 50 年の歩み, 技術講習会テキス卜 (1982) pp.63-76.

6）近角聡信編, 実験物理学講座 17 磁気（1968）pp.218224 , 共立出版. 